Randomized Trial

\title{
Effect of Fluoroscopically Guided Caudal Epidural Steroid or Local Anesthetic Injections in the Treatment of Lumbar Disc Herniation and Radiculitis: A Randomized, Controlled, Double Blind Trial with a Two-Year Follow-Up
}

Laxmaiah Manchikanti, MD1, Vijay Singh, MD², Kimberly A. Cash, RT',

Vidyasagar Pampati, MSc', Kim S. Damron, RN ${ }^{1}$, and Mark V. Boswell, MD, PhD

From: ${ }^{\text {PPain Management }}$ Center of Paducah, Paducah, KY; 'University of Louisville, Louisville, KY; and ${ }^{3}$ Spine Pain Diagnostics Associates, Niagara, WI.

Dr. Manchikanti is Medical Director of the Pain Management

Center of Paducah, Paducah, Kentucky and Clinical Professor, Anesthesiology and Perioperative Medicine, University of Louisville, Louisville, Kentucky.

Dr. Singh is Medical Director, Spine Pain Diagnostics Associates, Niagara, WI.

Kimberly A. Cash is a Research Coordinator at the Pain Management Center of Paducah, Paducah, KY

Vidyasagar Pampati is Statistician at the Pain Management Center of Paducah, Paducah, KY.

Kim S. Damron is a Nursing

Administrator at the Pain Management Center of Paducah, Paducah, KY.

Dr. Boswell is Chairman, Department of Anesthesiology and Perioperative Medicine, University

of Louisville, Louisville, KY

Address Correspondence: Laxmaiah Manchikanti, M.D. 2831 Lone Oak Road

Paducah, Kentucky 42003

E-mail: drlm@thepainmd.com

Disclaimer: There was no external funding in the preparation of this manuscript.

Conflict of interest: None.

Manuscript received: 05/24/2012 Accepted for publication: 06/07/2012

Free full manuscript: www.painphysicianjournal.com
Background: Lumbar disc herniation and radiculitis are common elements of low back and lower extremity pain. Among minimally invasive treatments, epidural injections are one of the most commonly performed interventions. However, the literature is mixed about their effectiveness in managing low back and lower extremity pain. In general, individual studies and systematic reviews of epidural steroid injections have been hampered by their study design, baseline differences between treatment groups, inadequate sample sizes, highly controlled settings, lack of validated outcome measures, and the inability to confirm the injectate location because fluoroscopy was not used.

Study Design: A randomized, controlled, double blind, active control trial.

Setting: A private, interventional pain management practice, specialty referral center in the United States.

Objectives: To assess the effectiveness of fluoroscopically directed caudal epidural injections with local anesthetic with or without steroids in managing chronic low back and lower extremity pain in patients with disc herniation and radiculitis.

Methods: One hundred twenty patients were randomized to two groups: Group I received 10 $\mathrm{mL}$ caudal epidural injections of local anesthetic, lidocaine $0.5 \%$; Group II patients received caudal epidural injections of $0.5 \%$ lidocaine, $9 \mathrm{~mL}$, mixed with $1 \mathrm{~mL}$ of steroid.

Outcome Assessment: Multiple outcome measures were utilized. The primary outcome measures were Numeric Rating Scale (NRS) and the Oswestry Disability Index 2.0 (ODI). Secondary outcome measures were employment status and opioid intake.

Significant pain relief improvement was defined as 50\% or more improvement in NRS and ODI scores.

Results: In the successful category, $77 \%$ of Group I had significant pain relief of $\geq 50 \%$ and functional status improvement of $\geq 50 \%$ reduction in ODI scores; in Group II it was 76\%, whereas overall it was $60 \%$ and $65 \%$ in Groups I and II. Over the two years, Group I had an average number of procedures of $5.5 \pm 2.8$; Group II was $5.3 \pm 2.4$. Even though there was no significant difference in overall relief between the two groups, the average relief for each procedure was superior for steroids.

Limitations: Presumed limitations of this evaluation include lack of a placebo group

Conclusion: Caudal epidural injections of local anesthetic with or without steroids might be an effective therapy for patients with disc herniation or radiculitis. The present evidence illustrates the potential superiority of steroids compared with local anesthetic at two year follow up based on average relief per procedure.

Key words: Chronic low back pain, caudal epidural injections, disc herniation, radiculitis, lower extremity pain, local anesthetic, steroids

Trial Registration: NCT00370799

Pain Physician 2012; 15:273-286 
O ver the past 77 years, voluminous literature has been written describing the epidemiology, diagnosis, and numerous treatment modalities for herniated disc pain, following the description of disc herniation by Mixter and Barr in 1934 (1-26). The estimated prevalence of lumbar radiculopathy or sciatica has been described as 9.8 per 1,000 cases (4), $5.1 \%$ in men and $3.7 \%$ in women (3). However, lumbar radiculopathy secondary to disc herniation resolves spontaneously in $23 \%$ to $48 \%$ of patients, but up to $30 \%$ to $70 \%$ will still have pronounced symptoms after one year, with $5 \%$ to $15 \%$ of patients undergoing surgery resulting in high economic impact and strain on health services $(6,7,16,24$ 26). Among minimally invasive treatments, epidural injections are one of the most commonly performed interventions $(2,17-21,24-33)$. However, the literature is mixed about their effectiveness in managing low back and lower extremity pain $(2,17,20,21,24-32)$. In general, individual studies and systematic reviews of epidural steroid injections have been hampered by their study design, baseline differences between treatment groups, inadequate sample sizes, highly controlled settings, lack of validated outcome measures, and the inability to confirm the injectate location because fluoroscopy was not used $(2,17,20,21,25-38)$. Other problems include inappropriate methodology, improper study evaluation, and evidence synthesis for systematic reviews $(2,17,21,25,26,31-33)$. Further, the three different approaches, caudal, interlaminar, and transforaminal, are used to treat multiple pathologies including disc herniation, axial or discogenic pain, spinal stenosis, and lumbar postsurgery syndrome along with other causes of low back pain. Thus, combining patients and/or results yielded significant confusion. Incorrect needle placement has been demonstrated in $20 \%$ to $38 \%$ of patients who have caudal epidural injections without fluoroscopy (34-38). Consequently, most systematic reviews $(2,20,21,25,26,31-33)$ have included non-fluoroscopically guided studies; some recent studies also were published without fluoroscopy $(27,29)$. Recently, Manchikanti et al $(30)$ published the results of fluoroscopic caudal epidural injections in the treatment of lumbar disc herniation and radiculitis in a randomized, controlled, double blind trial and showed the proportion of patients with significant pain relief of $50 \%$ or greater and/or improvement in functional status with $50 \%$ or more reduction in ODI scores to be $70 \%$ and $67 \%$ in patients receiving local anesthetic only, and $77 \%$ and $75 \%$ in patients receiving steroids with average procedures per year of 3.8. In contrast, Iversen et al (27) in a recent multicenter, blinded, randomized control trial evaluating the effect of caudal epidural steroid or saline injection for chronic lumbar radiculopathy without fluoroscopy, at 52 weeks showed no significant difference among placebo injection of 2 $\mathrm{mL}$ of sodium chloride solution over the sacral hiatus, $40 \mathrm{~mL}$ injection of sodium chloride solution into the epidural space, or $40 \mathrm{mg}$ of triamcinolone mixed with $40 \mathrm{~mL}$ of sodium chloride solution.

The multiple differences between these studies can be attributed to Iversen et al (27) using ultrasound, a technique which has not been proven to identify the caudal epidural space accurately. On the other hand, Manchikanti et al (30) used fluoroscopy. There were also multiple flaws with the design, conduct, and interpretation of the results with probable inclusion of acute pain patients, inappropriate conservative management since a significant proportion of patients improved prior to their randomization or starting treatment, using large volumes that diluted the steroid, and the lack of use of local anesthetic $(27,39,40)$. Further, approximately $40 \%$ of the patients were excluded with neurologic problems that did not fit the inclusion criteria, including a large proportion of patients with arachnoiditis, a rare condition (27).

In contrast, Manchikanti et al (30) conducted the study in a truly chronic population who had disc herniation and radiculitis for at least six months and who had failed conservative management. In this study fluoroscopy was used and injections were performed based on the return of pain and deterioration in functional status.

Thus, there continues to be conflicting evidence regarding the benefit of epidural steroid injections with or without local anesthetic. Thus far, only three randomized, controlled trials have been published evaluating mid term or long term outcomes with fluoroscopically guided caudal epidural injections $(28,30,41)$. Ackerman and Ahmed (41) only reported outcomes at 24 weeks in 30 patients. Dashfield et al (28) utilized only one injection when comparing endoscopic delivery of steroids in 27 patients and only six months of follow up. Even so, they reported positive results. The results of Manchikanti et al (30) with one year followup were positive in a practical, clinical setting.

This study was undertaken to evaluate the role of caudal epidural injections in patients with chronic low back and lower extremity pain secondary to disc herniation and radiculitis. This report is a continuation 
of the results of a previous publication (30) reflecting the results of the comparative effectiveness of caudal epidural injections of local anesthetic with or without steroids. This report contains data from the long term followup of two years.

\section{Methods}

This randomized, double blind, controlled trial was conducted based on the Consolidated Standards of Reporting Trials (CONSORT) (42). The study was approved by the Institutional Review Board (IRB) and was registered with the U.S. Clinical Trial Registry. It was conducted in an interventional pain management practice in the United States. Patients were recruited from new patients presenting to a single pain management center.

\section{Interventions}

All patients were provided with the approved protocol and informed consent that described the study and withdrawal process.

Patients were assigned into two groups. Group I patients received caudal epidural injections under fluoroscopy of local anesthetic (lidocaine $0.5 \%$ ), while Group II patients received caudal epidural injections of lidocaine mixed with steroids.

\section{Pre-Enrollment Evaluation}

The preenrollment evaluation consisted of specific data and outcome parameters. Outcome parameters included numeric rating scale (NRS), Oswestry Disability Index 2.0 (ODI), work status, and opioid intake. Demographic data included medical and surgical history with coexisting disease(s), radiologic investigations, and physical examination findings.

\section{Inclusion Criteria}

For patients to be included in the study, essential requirements were demonstrated disc herniation with radiculitis; age over 18 years; function limiting low back and lower extremity pain of at least six months; and, finally, patients who were competent and willing to participate in the study protocol and who could provide voluntary, written informed consent.

Exclusion criteria were: patients with a previous history of lumbar surgery; radiculitis secondary to either central or foraminal stenosis; no disc herniation; uncontrollable or unstable opioid use; uncontrollable psychiatric disorders; uncontrolled medical illness, either acute or chronic; pregnant or lactating women; a history or potential for adverse reactions from local anesthetic or steroid; and any conditions that could interfere with the interpretation of the outcome measurements.

\section{Description of Interventions}

All caudal epidural procedures were performed by one physician in an ambulatory surgery setting, in a sterile operating room, under fluoroscopy, with an \#18 gauge Tuohy needle, with the patient in the prone position. Appropriate monitoring with intravenous access and sedation with midazolam and fentanyl were provided as needed. Access to the epidural space was confirmed by injection of non-ionic contrast medium, followed by injection of $10 \mathrm{~mL}$ of lidocaine hydrochloride $0.5 \%$ preservative free into 60 Group I patients, and in Group II $9 \mathrm{~mL}$ of lidocaine mixed with $6 \mathrm{mg}$ of betamethasone (either brand name or non-particulate) or $40 \mathrm{mg}$ of methylprednisolone was injected. Twenty patients in Group II each received one of the three steroids.

\section{Additional Interventions}

Additional or repeat caudal epidural injections were provided on the basis of the patient's response, either after unblinding or without unblinding. All unblinded patients were considered to be withdrawn from the study. Non-responsive patients who did not receive further interventions were followed without unblinding.

\section{Cointerventions}

There were no specific cointerventions or additional interventions. However, all patients continued previous exercise programs, drug therapy, and work.

\section{Objectives}

The design of the study was a randomized, double blind, active control to evaluate the effectiveness of caudal epidural injections with or without steroids in managing chronic low back and lower extremity pain secondary to disc herniation or radiculitis.

\section{Outcomes}

The primary outcomes were pain relief and functional status improvement based on NRS pain scales and ODI disability scale. The secondary outcomes were employment and opioid intake.

The NRS pain scale (0-10), the ODI disability scale on a 0 to 50 scale, employment status, and opioid intake in terms of morphine equivalents were assessed at $3,6,12,18$, and 24 months posttreatment. The reliability of the NRS and ODI have been reported $(43,44)$. 
Significant pain relief and functional improvement of $50 \%$ or more reduction in NRS or ODI from baseline have been deemed appropriate (45-50).

The opioid intake was converted into morphine equivalents on the basis of the dosage frequency and schedule of the drug (51).

Employment and work status were classified into multiple categories based on present employment, unemployment due to pain, housewife with no desire to work outside the home, retirement, or over the age of 65 years. Patients who were unemployed because of pain or employed but on sick leave or laid off were considered as employable.

Patient response was considered successful if a patient obtained consistent relief lasting at least a total of three weeks with the first two procedures. Patients with less than three weeks of relief were considered as failures.

\section{Sample Size}

Sample size was calculated on the basis of significant pain relief and improvement in functional status. Considering a 0.05 two sided significance level, a power of $80 \%$, and an allocation ratio of $1: 1,55$ patients in each group were estimated (52). Allowing for a $10 \%$ attrition/non-compliance rate, 60 patients were required.

A previous Cochrane systematic review of epidural injections (33), and multiple other studies (45-50) identified 50 to 60 patients as acceptable; others have identified even smaller samples $(27,53)$.

\section{Randomization}

Sixty patients were randomly assigned into each group, for a total of 120 patients.

\section{Sequence Generation}

A computer generated random allocations sequence by simple randomization was used for randomization.

\section{Allocation Concealment}

Based on randomization, drugs were prepared by the operating room nurse assisting with the procedure.

\section{Implementation}

Patients meeting inclusion criteria were invited to enroll in the study. One of the three nurse coordinators of the study enrolled the participants and assigned participants to their

\section{Blinding (Masking)}

Participants, those administering the interventions, and all others involved in patient care were blinded to the group assignments. The blinding was also assured by mixing the patients with other patients receiving routine treatment and not informing the physician performing the procedure of the inclusion of the patients in the study or their group assignment.

\section{Statistical Methods}

Data analyses were carried out using the Statistical Package for Social Sciences version 9.01 (SPSS Inc, Chicago, IL). For categorical and continuous data comparison, Chi-square (Fisher test where necessary) and t test were used respectively. Because the outcome measures of the participants were measured at 4 points in time, repeated measures analysis of variance were performed with the post hoc analysis. A P value of less than 0.05 was considered significant.

There were no significant differences noted among the three subgroups receiving steroids in any outcome parameters or the frequency of interventions. Thus, the three subgroups receiving steroids were considered as one group (group II).

\section{Intent-to-Treat Analysis}

An intent-to-treat analysis was performed. A sensitivity analysis with changes in the NRS was performed utilizing the last follow-up score, best case scenario, and worst case scenario if there were no significant differences; the intent-to-treat analysis with last follow-up visit was used.

\section{Results}

\section{Patient Flow}

Figure 1 illustrates the participant flow.

\section{Recruitment}

The recruitment period started in January 2007 and ended in October 2009.

\section{Baseline Characteristics}

Table 1 illustrates the baseline demographic and clinical characteristics of each group.

There were differences in the demographic characteristics with respect to age, weight, and mode of pain onset. 


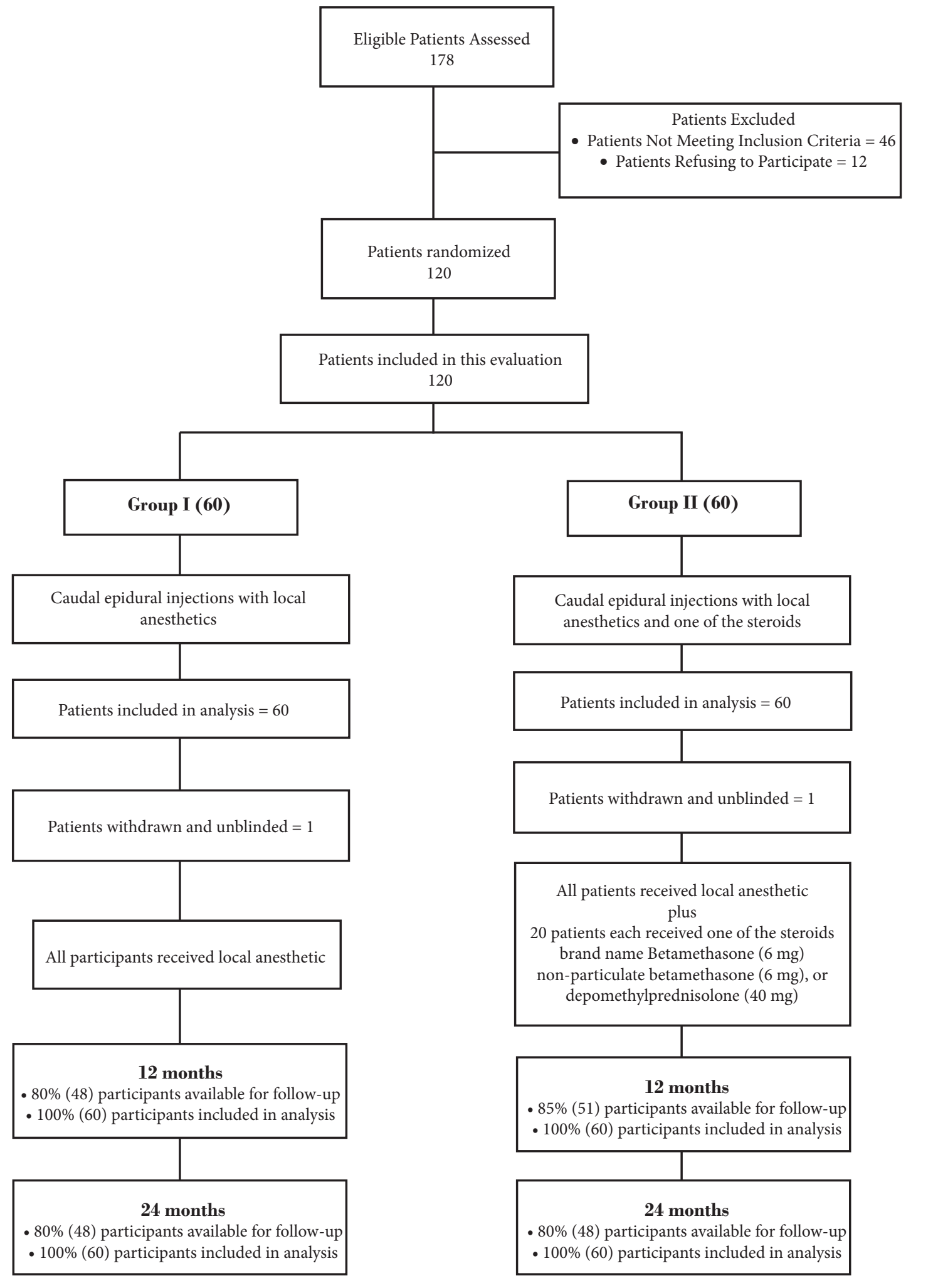

Fig. 1. Schematic presentation of patient flow at 2 year follow-up of 60 patients. 
Table 1. Baseline demographic characteristics.

\begin{tabular}{|c|c|c|c|c|}
\hline & & $\begin{array}{c}\text { Group } 1 \\
(60)\end{array}$ & $\begin{array}{c}\text { Group II } \\
(60)\end{array}$ & $P$ value \\
\hline \multirow{2}{*}{ Sex } & Male & $32 \%(19)$ & $38 \%(23)$ & \multirow{2}{*}{0.566} \\
\hline & Female & $68 \%(41)$ & $62 \%(37)$ & \\
\hline Age & Mean \pm SD & $48.7 \pm 14.1$ & $43.0 \pm 14.5$ & 0.031 \\
\hline Weight & Mean \pm SD & $208.3 \pm 53.9$ & $177.5 \pm 46.8$ & 0.001 \\
\hline Height & Mean \pm SD & $66.2 \pm 3.5$ & $66.6 \pm 4.0$ & 0.580 \\
\hline Duration of Pain (Months) & Mean \pm SD & $93.4 \pm 86.9$ & $81.3 \pm 81.7$ & 0.436 \\
\hline \multirow{2}{*}{ Onset of Pain } & Gradual & $72 \%(43)$ & $52 \%(31)$ & \multirow{2}{*}{0.034} \\
\hline & Injury & $28 \%(17)$ & $48 \%(29)$ & \\
\hline Numeric Rating Score & Mean \pm SD & $8.1 \pm 0.9$ & $7.8 \pm 0.9$ & 0.077 \\
\hline Oswestry Disability Index & Mean \pm SD & $29.2 \pm 4.6$ & $27.9 \pm 4.8$ & 0.158 \\
\hline \multirow{3}{*}{$\begin{array}{l}\text { Disc Herniation * } \\
\text { (levels) }\end{array}$} & $\mathrm{L} 3 / 4$ & $8 \%(5)$ & $5 \%(3)$ & \multirow{3}{*}{ NS } \\
\hline & $\mathrm{L} 4 / 5$ & $67 \%(40)$ & $70 \%(42)$ & \\
\hline & $\mathrm{L} 5 / \mathrm{S} 1$ & $58 \%(35)$ & $50 \%(30)$ & \\
\hline
\end{tabular}

${ }^{*}$ Multiple patients presented with disc herniation at more than one level.

\section{Analysis of Outcomes}

\section{Pain Relief \& Functional Assessment}

Table 2 presents the results of repeated measures analysis. There were significant differences in participants' average pain scores within group by time $(P<$ $0.0001)$, and no significant differences between two groups $(P=0.802)$. In the Oswestry Disability Index for functional status, there were significant differences in summary scores within group by time $(P=0.001)$ and no significant differences between two groups $(P=0.705)$. Paired samples t-test analysis indicates that mean differences baseline and the other five time points within the group were significant at the 0.05 level.

\section{Employment Characteristics}

Table 3 illustrates employment characteristics.

\section{Opioid Intake}

Table 4 illustrates opioid intake converted to morphine equivalents.

\section{Therapeutic Procedural Characteristics}

Therapeutic procedural characteristics and average pain relief data are illustrated in Table 5 . The relief at- tained was significantly higher in Group II, the group that received steroids, compared with Group I for the first two procedures; the average relief per procedure over two years was also higher in Group II. When patients were separated into successful and failed groups, the total number of injections per year was $4.3 \pm 1.0$ and $6.5 \pm 2.4$ for two years in Group I and $3.8 \pm 1.0$ per year and $5.8 \pm 2.2$ for two years in Group II in the successful group. Total relief was $70.1 \pm 30.8$ weeks in Group I and $76.5 \pm 27.7$ weeks in Group II for two years in successful category.

Figure 2 illustrates outcome data percentages of all participants, failed participants, and successful participants.

\section{Changes in Weight}

There were no differences in change (gain or loss) in body weight from baseline within the groups (Table $6)$.

\section{Adverse Events}

There were no major adverse events reported over a period of two years in all 120 patients. 
Caudal Epidural Steroid Injectiions in the Treatment of Lumbar Disc Herniation and Radiculits

Table 2. Comparison of Numeric Rating Scale for pain and Oswestry Disability Index score summaries at 4 time points.

\begin{tabular}{|c|c|c|c|c|}
\hline \multirow{3}{*}{ Time Points } & \multicolumn{2}{|c|}{ Numeric Pain Rating scale } & \multicolumn{2}{|c|}{ "Oswestry Disability Index } \\
\hline & Group I (60) & Group II (60) & Group I (60) & Group II (60) \\
\hline & Mean \pm SD & Mean \pm SD & Mean \pm SD & Mean \pm SD \\
\hline Baseline & $8.1 \pm 0.9$ & $7.8 \pm 0.9$ & $29.2 \pm 4.6$ & $27.9 \pm 4.8$ \\
\hline 3 months & $\begin{array}{c}4.1^{*} \pm 1.8 \\
(77 \%)\end{array}$ & $\begin{array}{c}3.4^{*} \pm 1.7 \\
(80 \%)\end{array}$ & $\begin{array}{c}16.5^{*} \pm 7.2 \\
(62 \%)\end{array}$ & $\begin{array}{c}13.6^{*} \pm 6.5 \\
(73 \%)\end{array}$ \\
\hline 6 months & $\begin{array}{c}3.9^{\star} \pm 1.8 \\
(77 \%)\end{array}$ & $\begin{array}{c}3.5^{\star} \pm 1.7 \\
(82 \%)\end{array}$ & $\begin{array}{c}15.5^{\star} \pm 7.3 \\
(72 \%)\end{array}$ & $\begin{array}{c}13.7^{\star} \pm 7.0 \\
(73 \%)\end{array}$ \\
\hline 12 months & $\begin{array}{c}4.1^{\star} \pm 1.8 \\
(70 \%)\end{array}$ & $\begin{array}{c}3.5^{\star} \pm 1.9 \\
(77 \%)\end{array}$ & $\begin{array}{c}15.5^{\star} \pm 7.74 \\
(67 \%)\end{array}$ & $\begin{array}{c}13.1^{\star} \pm 7.0 \\
(75 \%)\end{array}$ \\
\hline 18 months & $\begin{array}{c}4.1^{\star} \pm 1.8 \\
(65 \%)\end{array}$ & $\begin{array}{c}3.5^{\star} \pm 1.8 \\
(75 \%)\end{array}$ & $\begin{array}{c}15.5^{\star} \pm 7.4 \\
(62 \%)\end{array}$ & $\begin{array}{c}13.2^{\star} \pm 6.7 \\
(77 \%)\end{array}$ \\
\hline 24 months & $\begin{array}{c}4.2^{\star} \pm 1.8 \\
(63 \%)\end{array}$ & $\begin{array}{c}3.6^{*} \pm 1.8 \\
(68 \%)\end{array}$ & $\begin{array}{c}15.6^{*} \pm 7.3 \\
(60 \%)\end{array}$ & $\begin{array}{c}13.5^{*} \pm 7.2 \\
(70 \%)\end{array}$ \\
\hline Group Difference & \multicolumn{2}{|c|}{0.802} & \multicolumn{2}{|c|}{0.705} \\
\hline Time Difference & \multicolumn{2}{|c|}{0.001} & \multicolumn{2}{|c|}{0.001} \\
\hline Group by Time Interaction & \multicolumn{2}{|c|}{0.036} & \multicolumn{2}{|c|}{0.053} \\
\hline
\end{tabular}

Lower the value indicates better condition

* significant difference with baseline values within the group $(\mathrm{P}<0.05)$

(_) illustrates proportion with significant pain relief $(\geq 50 \%)$ from baseline

Table 3. Employment characteristics.

\begin{tabular}{|c|c|c|c|c|c|c|}
\hline \multirow{2}{*}{ Employment status } & \multicolumn{3}{|c|}{ Group I } & \multicolumn{3}{|c|}{ Group II } \\
\hline & Baseline & 12 Months & 24 Months & Baseline & 12 Months & 24 Months \\
\hline Employed Part-time & 2 & 3 & 3 & 7 & 6 & 5 \\
\hline Employed Full-time & 9 & 13 & 13 & 8 & 20 & 20 \\
\hline Unemployed & 5 & 1 & 1 & 11 & 1 & 1 \\
\hline Total Employed & 11 & 17 & 17 & 15 & 26 & 25 \\
\hline Eligible for Employment & 16 & 16 & 16 & 26 & 26 & 26 \\
\hline Housewife & 5 & 4 & 3 & 5 & 4 & 4 \\
\hline Disabled & 31 & 31 & 32 & 23 & 23 & 24 \\
\hline Over 65 Years Old & 8 & 8 & 8 & 6 & 6 & 6 \\
\hline Total Number of Patients & 60 & 60 & 60 & 60 & 60 & 60 \\
\hline
\end{tabular}

\section{Discussion}

This randomized, active control trial of 120 patients with chronic persistent low back and lower extremity pain secondary to disc herniation and radiculitis, assessing caudal epidural injections with or without steroids, showed clinically meaningful and significant improvement in all parameters at the end of a two year period. The results of this study illustrate that in carefully selected patients, judged as successful participants who responded to the first two initial procedures, combined pain relief and improvement in functional status was observed in $77 \%$ in Group I and $76 \%$ in Group II at two year follow up. However, overall improvement was also significant with $60 \%$ of the patients showing improvement in Group I and $65 \%$ of the patients in Group II. Consequently, this study confirms the failure of the null hypothesis that treatment of chronic lumbar radiculopathy with caudal epidural injections of 
Table 4. Opioid intake (morphine equivalents in mg).

\begin{tabular}{|l|c|c|}
\hline \multirow{2}{*}{$\begin{array}{l}\text { Opioid Intake } \\
\text { Morphine Equivalents in mg) }\end{array}$} & Group I (60) & Group II (60) \\
\cline { 2 - 3 } & Mean \pm SD & Mean \pm SD \\
\hline Baseline & $51.8 \pm 58.6$ & $45.0 \pm 57.8$ \\
\hline 3 Months & $32.8^{*} \pm 31.6$ & $30.1 \pm 31.8$ \\
\hline 6 Months & $32.9^{*} \pm 31.6$ & $31.1 \pm 37.5$ \\
\hline 12 Months & $32.8^{*} \pm 31.6$ & $31.1 \pm 37.5$ \\
\hline 18 Months & $32.8^{*} \pm 31.6$ & $31.1 \pm 37.5$ \\
\hline 24 Months & $32.8^{*} \pm 31.6$ & $31.1 \pm 37.5$ \\
\hline Group Difference & & 0.753 \\
\hline Time Difference & \multicolumn{2}{|c|}{0.004} \\
\hline Group by Time Interaction & 0.492 \\
\hline
\end{tabular}

${ }^{*}$ significant difference with baseline values $(\mathrm{P}<0.05)$

Table 5. Therapeutic procedural characteristics with procedural frequency, average relief per procedure, and average total relief in weeks over a period of one and two years.

\begin{tabular}{|c|c|c|c|c|c|c|}
\hline & \multicolumn{2}{|c|}{ Puccessful Patients } & \multicolumn{2}{|c|}{ Failed Patients } & \multicolumn{2}{|c|}{ 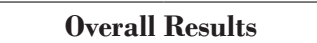 } \\
\hline & $\begin{array}{l}\text { Group I } \\
(47)\end{array}$ & $\begin{array}{l}\text { Group II } \\
\quad(50)\end{array}$ & $\begin{array}{l}\text { Group I } \\
\text { (13) }\end{array}$ & $\begin{array}{l}\text { Group II } \\
\quad(10)\end{array}$ & $\begin{array}{c}\text { Group I } \\
(60)\end{array}$ & $\begin{array}{l}\text { Group II } \\
\quad(60)\end{array}$ \\
\hline Average Number of Procedures First Year & $4.3 \# \pm 1.0$ & $3.8 \pm 1.0$ & $2.1 \pm 1.2$ & $2.5 \pm 1.2$ & $3.8 \pm 1.4$ & $3.6 \pm 1.1$ \\
\hline Average Number of Procedures Over 2 Years & $6.5 \pm 2.4$ & $5.8 \pm 2.2$ & $2.2 \pm 1.1$ & $2.6 \pm 1.4$ & $5.5 \pm 2.8$ & $5.3 \pm 2.4$ \\
\hline $\begin{array}{l}\text { Average Relief per Procedure for Initial } 2 \\
\text { Procedures in Weeks (Maximum) }\end{array}$ & $\begin{array}{l}6.6^{*} \pm 3.8 \\
(17 \text { weeks })\end{array}$ & $\begin{array}{l}11.3 \pm 14.6 \\
(100 \text { weeks })\end{array}$ & $\begin{array}{l}1.4 \pm 2.2 \\
(8 \text { weeks })\end{array}$ & $\begin{array}{c}1.3 \pm 2.6 \\
(11 \text { weeks })\end{array}$ & $\begin{array}{l}5.6^{*} \pm 4.1 \\
(17 \text { weeks })\end{array}$ & $\begin{array}{c}9.7 \pm 13.9 \\
(100 \text { weeks })\end{array}$ \\
\hline $\begin{array}{l}\text { Average Relief per Procedure After Initial } \\
2 \text { Procedures (Maximum) }\end{array}$ & $\begin{array}{l}12.7^{\star} \pm 3.5 \\
(36 \text { weeks })\end{array}$ & $\begin{array}{l}14.4 \pm 9.2 \\
(94 \text { weeks) }\end{array}$ & $\begin{array}{c}4.8 \pm 5.4 \\
(13 \text { weeks })\end{array}$ & $\begin{array}{c}7.3 \pm 9.4 \\
(26 \text { weeks })\end{array}$ & $\begin{array}{l}12.5^{\star} \pm 3.7 \\
(36 \text { weeks })\end{array}$ & $\begin{array}{l}14.1 \pm 9.2 \\
(94 \text { weeks) }\end{array}$ \\
\hline Average Relief per Procedure & $10.8^{\star} \pm 4.7$ & $13.3 \pm 11.4$ & $2.1 \pm 3.4$ & $2.9 \pm 5.8$ & $10.1^{\star} \pm 5.0$ & $12.5 \pm 11.4$ \\
\hline Average Total Relief First Year (Weeks) & $40.7 \pm 11.4$ & $42.7 \pm 11.0$ & $4.5 \pm 7.1$ & $7.1 \pm 10.4$ & $32.9 \pm 18.4$ & $36.8 \pm 17.2$ \\
\hline Average Total Relief Over 2 Years (Weeks) & $70.1 \pm 30.8$ & $76.5 \pm 27.7$ & $4.5 \pm 7.0$ & $7.5 \pm 11.7$ & $55.9 \pm 38.6$ & $65.0 \pm 36.5$ \\
\hline
\end{tabular}

* significant difference Group II $(\mathrm{P}<0.05)$

Successful group - At least three weeks of relief with first 2 procedures

$\square$ Group I घ Group II

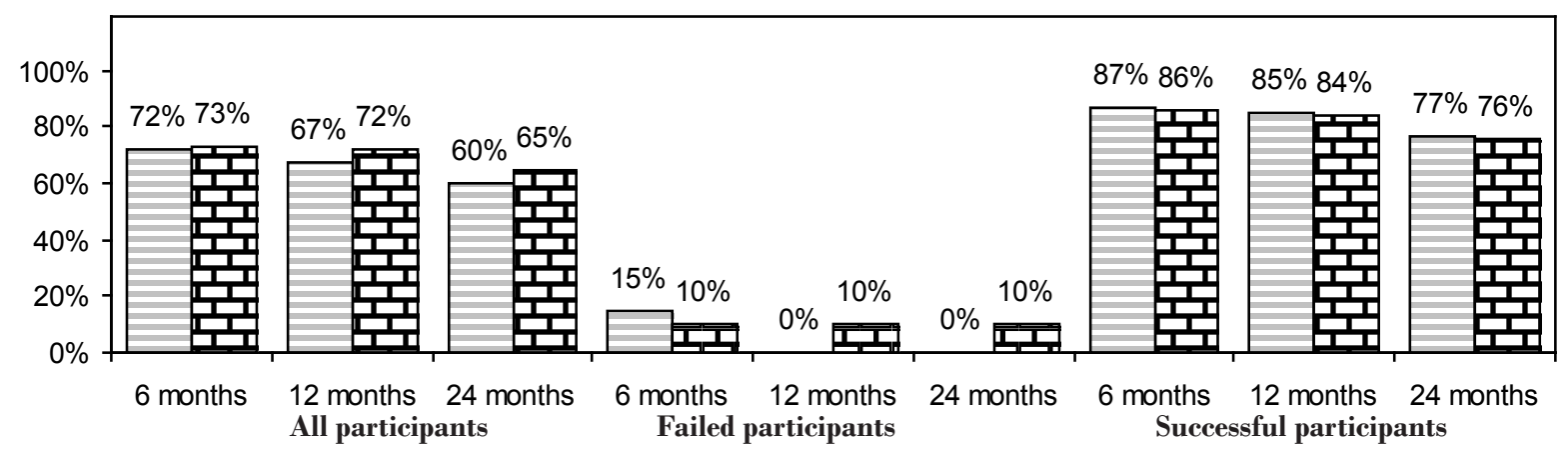

Fig. 2. Proportion of patients with significant reduction in Numeric Rating Score and Oswestry Disability Index ( $\geq 50 \%$ reduction from baseline). 
Table 6. Characteristics of weight monitoring.

\begin{tabular}{|c|c|c|c|}
\hline \multirow{2}{*}{ Weight (lbs) } & Group I (60) & Group II (60) & \multirow{2}{*}{$P$ value } \\
\hline & Mean \pm SD & Mean \pm SD & \\
\hline Weight at Beginning & $208.3 \pm 53.9$ & $177.5 \pm 46.8$ & 0.001 \\
\hline Weight at One Year & $202.9 \pm 52.2$ & $176.8 \pm 46.8$ & 0.009 \\
\hline Change & $5.3 \pm 10.9$ & $0.9 \pm 15.0$ & 0.014 \\
\hline Lost Weight & $27 \%(16)$ & $37 \%(22)$ & \multirow{3}{*}{0.495} \\
\hline No Change & $18 \%(11)$ & $15 \%(9)$ & \\
\hline Gained Weight & $55 \%(33)$ & $48 \%(29)$ & \\
\hline Weight at Two Years & $202.4 \pm 52.9$ & $178.0 \pm 46.8$ & 0.009 \\
\hline Change & $-5.9 \pm 12.8$ & $0.5 \pm 9.7$ & 0.003 \\
\hline Lost Weight & $53 \%(32)$ & $50 \%(30)$ & \multirow{3}{*}{0.047} \\
\hline No Change & $22 \%(13)$ & $8 \%(5)$ & \\
\hline Gained Weight & $25 \%(15)$ & $42 \%(25)$ & \\
\hline
\end{tabular}

steroids or local anesthetic has no clinically important effect. Instead, it confirms that the treatment of lumbar disc herniation with radiculopathy with caudal epidural injection of steroids or local anesthetics has clinically important effects, irrespective of the steroid utilized, whether it is methylprednisolone, brand name betamethasone, or non-particulate betamethasone mixed with local anesthetic. While the average total relief over two years was not significantly different-70.1 \pm 30.8 weeks in Group I and $76.5 \pm 27.7$ weeks in Group II in the successful group - the average relief per procedure for the initial two procedures, as well as subsequent procedures and overall procedures over the period of two years, was significantly higher in Group II, not only in the successful patients, but also with reference to overall results. Thus, steroids indicate a potential superiority on a long term basis over a two year period, requiring approximately six procedures over two years, whereas it was slightly higher for Group I without steroids at 6.5 procedures for two years. We also observed a significant decrease in opioid intake from the baseline in Group I and an insignificant decrease in opioid intake in Group II along with an insignificant increase in employment in both groups at two years. At the end of two years, almost all of the patients eligible for employment in both groups were employed. We expected significant weight gains in the steroid group, however, there was no change noted in patients gaining weight at the end of one year. There was a significant proportion of patients gaining weight at the end of two years. This is significant since baseline weights were signifi- cantly higher in Group I, thus this finding may indicate that over a long-term period steroids may contribute to weight gain even though this change was absent at the end of one-year.

The literature is replete with multiple studies and systematic reviews in favor of and against epidural injections in general $(2,17,20,21,25-33)$. Multiple studies have been criticized, most importantly for their design and their inability to confirm the location of the injectate by not using fluoroscopy. Systematic reviews have been criticized for their methodology by evaluating the studies inappropriately; consequently their evidence synthesis has led to inaccurate conclusions.

In a systematic review by Conn et al (17) of randomized trials of caudal epidural injections for managing chronic low back pain of various origins, including disc herniation, only two trials met the inclusion criteria of long term follow up of at least six months and the use of fluoroscopic visualization $(28,54)$. They concluded that patients receiving caudal epidural injections with or without steroids had better results when the injections were performed under fluoroscopy. The authors did not include one study because of a 24 week follow up, which also showed positive results (41). Other systematic reviews $(20,21,33)$ have combined multiple approaches into one category; the majority of them did not use fluoroscopy.

Since the publication of these systematic reviews, new studies were published $(27,29,30)$ confirming the effectiveness of epidural injections $(29,30)$, even without fluoroscopy in one study (29), and showing nega- 
tive results in one study (27). Iversen et al (27) published a placebo controlled study under ultrasound without fluoroscopy showing negative results, however the study has been criticized for multiple flaws with design, conduct, patient selection, lack of fluoroscopy, and interpretation of the results $(39,40)$. Further, Cohen $(55)$ in an editorial accompanying Iversen et al (27), commented that overall epidural steroid injections seem to be beneficial, but only provide modest improvement in carefully selected patients with predominantly radicular symptoms. Cohen believed that there was no definitive answer and postulated multiple reasons for the failure of epidural steroid injections in Iversen et al's study (27). Despite the negative findings, Cohen believed that Iversen et al's study should not be misinterpreted as suggesting that epidural steroid injections are of no use in neuropathic back pain. He also commented that if only a small proportion of people return to work or can avoid surgery, epidural steroid injections may be considered as an effective adjunct when used judiciously. Thus, in the era of comparative effective research $(31,32,56-58)$, the evidence from comparative effectiveness or active controlled trials such as the present study are crucial in selecting a clinical intervention.

In recent years, comparative effectiveness research has been considered pivotal to evidence based medicine $(31,32,56-58)$. Even though the current study is limited to a single center, it is randomized, active controlled, and double blind, designed to determine whether fluoroscopically directed epidural injections with or without steroids with usual volumes injected in practice are helpful. Consequently, the results of this trial are applicable to interventional pain management in practical settings. Patient selection was not only practical but also was met with great sensitivity and included only patients with chronic persistent pain due to disc herniation and radiculitis. Consequently, this study meets the criteria for pragmatic or practical clinical trials with an active control group instead of a placebo group, and measures effectiveness, which is considered more appropriate than explanatory trials measuring efficacy (43,59-62). In addition, the current study was made as practical as possible by utilizing injection therapy with repeat caudal epidural injections based on the requirement that there be an increase in pain and deterioration in functional status prior to repeating the injection, rather than following a routine of a certain number of procedures, inappropriate assessment, and expecting one or two years of positive outcomes with one procedure. Further, as seen in contemporary spe- cialized practices, this study demonstrated that the first or the initial two procedures do not provide long term relief, and if the initial relief does not last more than three weeks, the procedures may not provide relief in patients on a long term basis as was observed in failed patients, and that it may be futile to continue to repeat these procedures in these patients, unless there are compelling reasons.

Further, this study may be criticized by not focusing on clinical aspects and as deficient because of the lack of a placebo group. However, most studies have utilized inappropriate methodology of placebo groups (27,63-68). The appropriate placebo design by Ghahreman et al (67) showed no significant effect with sodium chloride solution when injected into an inactive structure. Further, these concepts, including local anesthetic transformed into placebo, are not only methodologically and conceptually inaccurate, they also result in misleading conclusions since inactive substances injected into active structures have been shown to result in various types of effects (69-72) and local anesthetics have been shown to provide long term improvement in patients both in clinical as well as experimental settings (45-50,73-85).

Further, an Institute of Medicine (IOM) report states that the effectiveness of pain treatments depends greatly on the strength of the clinician-patient relationship: Pain treatment is never about the clinician's intervention alone, but about the clinician and the patient (and family) working together (86).

Finally, other weaknesses include differences in baseline demographic characteristics with respect to weight, age, and the pain's mode of onset. However, these differences may be considered minor and have not shown to have any effect on the final results.

Even though the mechanism of action of steroids and local anesthetics continues to be debated and multiple hypothesis are emerging, the evidence shows that steroids as well as local anesthetics have significant effects on the modulation of noxious stimulation by various mechanisms (73-78,87-90) with no significant difference whether local anesthetics are injected alone or with steroids (45-50,79-85).

Implications of this trial are enormous in an era of evidence based medicine, comparative effectiveness research, and exploding health care costs. Studies with proper methodology in practical settings are crucial. Proper application of the interventions will improve patient's pain function, reduce drug use, and may return them to the work force - a great benefit for society. 
However, inappropriate provision of any type of intervention, specifically one which incurs substantial expenses, will not provide any benefit, harm the patient, and deplete resources, thus reducing access. Similarly, inappropriately performed evaluations that lead to inaccurate conclusions may reduce health care expenditures, but will also increase patient suffering, reduce function, increase drug use, and finally impede access to medical care.

\section{Conclusion}

This randomized double blind, active controlled trial of 120 patients treated with fluoroscopically guided caudal epidural injections of local anesthetic with or without steroids for chronic low back and lower extremity pain secondary to disc herniation and radicu- litis, illustrated effectiveness in more than $75 \%$ of the patients with improvement in functional status, requiring an average of six procedures over two years and providing over 70 weeks of pain relief and function status improvement during the two year period in appropriately selected patients.

\section{Acknowledgments}

The authors wish to thank Sekar Edem for assistance in the search of the literature, Bert Fellows, MA, and Tom Prigge, MA, for manuscript review, and Tonie M. Hatton and Diane E. Neihoff, transcriptionists, for their assistance in preparation of this manuscript. We would like to thank the editorial board of Pain Physician for review and criticism in improving the manuscript.

\section{References}

1. Mixter WJ, Barr JS. Rupture of the intervertebral disc with involvement of the spinal canal. N Eng J Med 1934; 211:210215 .

2. Manchikanti L, Boswell MV, Singh V, Benyamin RM, Fellows B, Abdi S, Buenaventura RM, Conn A, Datta S, Derby R, Falco FJE, Erhart S, Diwan S, Hayek SM, Helm S, Parr AT, Schultz DM, Smith HS, Wolfer LR, Hirsch JA. Comprehensive evidence-based guidelines for interventional techniques in the management of chronic spinal pain. Pain Physician 2009; 12:699-802.

3. Konstantinou K, Dunn KM. Sciatica: Review of epidemiological studies and prevalence estimates. Spine (Phila $\mathrm{Pa}$ 1976) 2008; 33:2464-2472.

4. Savettieri G, Salemi G, Rocca WA, Meneghini F, D'Arpa A, Morgante L, ci MA, Reggio A, Grigoletto F, Di Perri R. Prevalence of lumbosacral radiculopathy in two Sicilian municipalities. Sicilian Neuro-Epidemiologic Study (SNES) Group. Acta Neurol Scand 1996; 93:464469.

5. Martin BI, Turner JA, Mirza SK, Lee MJ, Comstock BA, Deyo RA. Trends in health care expenditures, utilization, and health status among US adults with spine problems, 1997-2006. Spine (Phila Pa 1976) 2009; 34:2077-2084.

6. Hoy D, Brooks P, Blyth F, Buchbinder R. The epidemiology of low back pain. Best Pract Res Clin Rheumatol 2010; 24:769781.
7. Tosteson AN, Tosteson TD, Lurie JD, Abdu W, Herkowitz H, Andersson G, Albert T, Bridwell K, Zhao W, Grove MR, Weinstein MC, Weinstein JN. Comparative effectiveness evidence from the spine patient outcomes research trial: Surgical versus nonoperative care for spinal stenosis, degenerative spondylolisthesis, and intervertebral disc herniation. Spine (Phila Pa 1976) 2011; 36:20612068.

8. Ivanova JI, Birnbaum HG, Schiller M, Kantor E, Johnstone BM, Swindle RW. Real-world practice patterns, health-care utilization, and costs in patients with low back pain: The long road to guidelineconcordant care. Spine ] 2011; 11:622-632.

9. Freburger JK, Holmes GM, Agans RP, Jackman AM, Darter JD, Wallace AS, Castel LD, Kalsbeek WD, Carey TS. The rising prevalence of chronic low back pain. Arch Intern Med 2009; 169:251-258.

10. Luo X, Pietrobon R, Sun SX, Liu GG, Hey L. Estimates and patterns of direct health care expenditures among individuals with back pain in the United States. Spine (Phila Pa 1976) 2004; 29:79-86.

11. Rubinstein SM, van Middelkoop M, Assendelft WJ, de Boer MR, van Tulder MW. Spinal manipulative therapy for chronic low-back pain: An update of a Cochrane review. Spine (Phila Pa 1976) 2011; 36:E825-E846.

12. Chou R, Qaseem A, Owens DK, Shekelle P; Clinical Guidelines Committee of the American College of Physicians. Di- agnostic imaging for low back pain: Advice for high-value health care from the American College of Physicians. Ann Intern Med 2011; 154:181-189.

13. Baras JD, Baker LC. Magnetic resonance imaging and low back pain care for Medicare patients. Health Aff (Millwood) 2009; 28:w1133-w1140.

14. Hahne AJ, Ford JJ, McMeeken JM. Conservative management of lumbar disc herniation with associated radiculopathy: A systematic review. Spine (Phila Pa 1976) 2010; 35:E488-E504.

15. van Middelkoop M, Rubinstein SM, Kuijpers T, Verhagen AP, Ostelo R, Koes BW, van Tulder MW. A systematic review on the effectiveness of physical and rehabilitation interventions for chronic nonspecific low back pain. Eur Spine ] 2011; 20:19-39.

16. Jacobs WC, van Tulder M, Arts M, Rubinstein SM, van Middelkoop M, Ostelo R, Verhagen A, Koes B, Peul WC. Surgery versus conservative management of sciatica due to a lumbar herniated disc: A systematic review. Eur Spine J 2011;20:513-22.

17. Conn A, Buenaventura R, Datta S, Abdi S, Diwan S. Systematic review of caudal epidural injections in the management of chronic low back pain. Pain Physician 2009; 12:109-135.

18. Manchikanti L, Pampati V, Boswell MV, Smith HS, Hirsch JA. Analysis of the growth of epidural injections and costs 
in the Medicare population: A comparative evaluation of 1997, 2002, and 2006 data. Pain Physician 2010; 13:199-212.

19. Abbott ZI, Nair KV, Allen RR, Akuthota VR. Utilization characteristics of spinal interventions. Spine J 2012; 1:35-43.

20. Staal JB, de Bie RA, de Vet HC, Hildebrandt J, Nelemans P. Injection therapy for subacute and chronic low back pain: An updated Cochrane review. Spine (Phila Pa 1976) 2009; 34:49-59.

21. Chou R, Huffman L. Guideline for the Evaluation and Management of Low Back Pain: Evidence Review. American Pain Society, Glenview, IL, 2009.

www.ampainsoc.org/pub/pdf/LBPEvidRev.pdf

22. Manchikanti L, Fellows B, Ailinani $\mathrm{H}$, Pampati V. Therapeutic use, abuse, and nonmedical use of opioids: A ten-year perspective. Pain Physician 2010; 13:401435.

23. Manchikanti L, Ailinani H, Koyyalagunta D, Datta S, Singh V, Eriator I, Sehgal $\mathrm{N}$, Shah R, Benyamin R, Vallejo R, Fellows $B$, Christo PJ. A systematic review of randomized trials of long-term opioid management for chronic non-cancer pain. Pain Physician 2011; 14:91-121.

24. Deyo RA, Mirza SK, Turner JA, Martin BI. Overtreating chronic back pain: Time to back off? J Am Board Fam Med 2009; 22:62-68.

25. Manchikanti L, Singh V, Boswell MV. Interventional pain management at crossroads: The perfect storm brewing for a new decade of challenges. Pain Physician 2010; 13:E111-E140.

26. Benyamin RM, Datta S, Falco FJE. A perfect storm in interventional pain management: Regulated, but unbalanced. Pain Physician 2010;13:109-16.

27. Iversen $T$, Solberg $T$, Romner B, Wilsgaard T, Twisk J, Anke A, Nygaard O, Hasvold T, Ingebrigtsen T. Effect of caudal epidural steroid or saline injection in chronic lumbar radiculopathy: Multicentre, blinded, randomised controlled trial. BMJ 2011; 343:d 5278 .

28. Dashfield AK, Taylor MB, Cleaver JS, Farrow D. Comparison of caudal steroid epidural with targeted steroid placement during spinal endoscopy for chronic sciatica: A prospective, randomized, double-blind trial. Br J Anaesth 2005; 94:514-629.

29. Sayegh FE, Kenanidis El, Papavasiliou KA, Potoupnis ME, Kirkos JM, Kapetanos GA. Efficacy of steroid and non- steroid caudal epidural injections for low back pain and sciatica: A prospective, randomized, double-blind clinical trial. Spine (Phila Pa 1976) 2009; 34:14411447.

30. Manchikanti L, Singh V, Cash K, Vidyasagar P, Damron K, Boswell M. A randomized, controlled, double-blind trial of fluoroscopic caudal epidural injections in the treatment of lumbar disc herniation and radiculitis. Spine (Phila Pa 1976) 2011; 36:1897-1905.

31. Manchikanti L, Datta S, Gupta S, Munglani R, Bryce DA, Ward SP, Benyamin RM, Sharma ML, Helm S 2nd, Fellows B, Hirsch JA. A critical review of the American Pain Society clinical practice guidelines for interventional techniques: Part 2. Therapeutic interventions. Pain Physician 2010; 13:E215-E264.

32. Manchikanti L, Falco FJE, Boswell MV Hirsch JA. Facts, fallacies, and politics of comparative effectiveness research: Part 2. Implications for interventional pain management. Pain Physician 2010; 13:E55-E79.

33. Koes BW, Scholten RJ, Mens JM, Bouter LM. Efficacy of epidural steroid injections for low-back pain and sciatica: A systematic review of randomized clinical trials. Pain 1995; 63:279-288.

34. Manchikanti L, Cash KA, Pampati V, McManus CD, Damron KS. Evaluation of fluoroscopically guided caudal epidural injections. Pain Physician 2004; 7:81-92.

35. Cleary M, Keating C, Poynton AR. The flow patterns of caudal epidural in upper lumbar spinal pathology. Eur Spine ] 2011; 20:804-807.

36. Stitz MY, Sommer HM. Accuracy of blind versus fluoroscopically guided caudal epidural injection. Spine (Phila Pa 1976) 1999; 24:1371-1376.

37. White AH, Derby R, Wynne G. Epidural injections for the treatment of low back pain. Spine (Phila Pa 1976) 1980; 5:78-86.

38. Manchikanti L, Bakhit CE, Pampati V. The role of epidurography in caudal neuroplasty. Pain Digest 1998; 8:277-281.

39. Gupta S, Ward S, Munglani R, Sharma M. Letter to the Editor re: Iversen $T$, et al. Effect of caudal epidural steroid or saline injection in chronic lumbar radiculopathy: multicentre, blinded, randomised controlled trial. BMJ 2011; 343:d5278. Careful patient selection, fluoroscopy and contrast injection are needed for effective spinal injections. Published online 9/26/2011. Author's reply: Published online 9/29/2011.
40. Norman. Letter to the Editor re: Iversen $\mathrm{T}$, et al. Effect of caudal epidural steroid or saline injection in chronic lumbar radiculopathy: multicentre, blinded, randomised controlled trial. BM] 2011; 343:d5278. The effect of caudal epidural in chronic lumbar radiculopathy remains unclear. Published online 9/23/2011. Author's reply: Published online 9/24/2011.

41. Ackerman WE 3rd, Ahmad M. The efficacy of lumbar epidural steroid injections in patients with lumbar disc herniations. Anesth Analg 2007; 104:1217-1222.

42. Altman DG, Schulz KF, Moher D, Egger M, Davidoff F, Elbourne D, et al; CONSORT GROUP (Consolidated Standards of Reporting Trials). The revised CONSORT statement for reporting randomized trials: Explanation and elaboration. Ann Intern Med 2001;134:663-94.

43. Manchikanti L, Benyamin RM, Helm S, Hirsch JA. Evidence-based medicine, systematic reviews, and guidelines in interventional pain management: Part 3: Systematic reviews and meta-analyses of randomized trials. Pain Physician 2009; 12:35-72.

44. Fairbank JC, Pynsent PB. The Oswestry Disability Index. Spine (Phila Pa 1976) 2000; 25:2940-2952.

45. Manchikanti L, Cash KA, McManus CD, Pampati V, Smith HS. One year results of a randomized, double-blind, active controlled trial of fluoroscopic caudal epidural injections with or without steroids in managing chronic discogenic low back pain without disc herniation or radiculitis. Pain Physician 2011; 14:25-36.

46. Manchikanti L, Singh V, Cash KA, Pampati V, Datta S. Management of pain of post lumbar surgery syndrome: Oneyear results of a randomized, double double-blind, active controlled trial of fluoroscopic caudal epidural injections. Pain Physician 2010; 13:509-521.

47. Manchikanti L, Cash RA, McManus CD, Pampati V, Fellows B. Fluoroscopic caudal epidural injections with or without steroids in managing pain of lumbar spinal stenosis: One year results of randomized, double-blind, active-controlled trial. J Spinal Disord 2012; 25:226234 .

48. Manchikanti L, Singh V, Falco FJE, Cash KA, Pampati V. Evaluation of lumbar facet joint nerve blocks in managing chronic low back pain: A randomized, doubleblind, controlled trial with a 2-year follow-up. Int ] Med Sci 2010; 7:124-135. 
49. Manchikanti L, Singh V, Falco FJE, Cash KA, Fellows B. Comparative outcomes of a 2-year follow-up of cervical medial branch blocks in management of chronic neck pain: A randomized, double-blind controlled trial. Pain Physician 2010; 13:437-450.

50. Manchikanti L, Singh V, Falco FJ, Cash KA, Pampati V, Fellows B. Comparative effectiveness of a one-year follow-up of thoracic medial branch blocks in management of chronic thoracic pain: A randomized, double-blind active controlled trial. Pain Physician 2010; 13:535-548.

51. Pereira J, Lawlor P, Vigano A, Dorgan M, Bruera E. Equianalgesic dose ratios for opioids. A critical review and proposals for long-term dosing. J Pain Symptom Manage 2001; 22:672-687. Narcotic analgesic converter, GlobalRPh Inc. http:// www.globalrph.com/narcotic.cgi Accessed April 7, 2010.

52. Browner WS, Newman TB, Cummings SR, Hulley SB. Estimating sample size and power. In Hulley SB, Cummings SR, Browner WS, et al (eds). Designing Clinical Research: An Epidemiologic Approach, 2nd ed. Philadelphia, PA: Lippincott, Williams \& Wilkins, 2001, pp 65-84.

53. Gharibo C, Varlotta G, Rhame E, Liu EC), Bendo J, Perloff M. Interlaminar versus transforaminal epidural steroids for the treatment of sub-acute lumbar radicular pain: A randomized, blinded prospective outcome study. Pain Physician 2011; 14:499-511.

54. Manchikanti L, Singh V, Cash KA, Pampati V, Damron KS, Boswell MV. Preliminary results of randomized, equivalence trial of fluoroscopic caudal epidural injections in managing chronic low back pain: Part 2. Disc herniation and radiculitis. Pain Physician 2008; 11:801-815.

55. Cohen SP. Epidural steroid injections for low back pain. BMJ 2011; 343:d5310.

56. Manchikanti L, Falco FJ, Benyamin RM, Helm S 2nd, Parr AT, Hirsch JA. The impact of comparative effectiveness research on interventional pain management: Evolution from Medicare Modernization Act to Patient Protection and Affordable Care Act and the PatientCentered Outcomes Research Institute. Pain Physician 2011; 14:E249-E282.

57. Manchikanti L, Falco FJE, Boswell MV, Hirsch JA. Facts, fallacies, and politics of comparative effectiveness research: Part I. Basic considerations. Pain Physician 2010; 13:E23-E54.

58. Manchikanti L, Datta S, Derby R, Wolfer
LR, Benyamin RM, Hirsch JA. A critical review of the American Pain Society clinical practice guidelines for interventional techniques: Part 1. Diagnostic interventions. Pain Physician 2010; 13:E141E174.

59. Hotopf M. The pragmatic randomized controlled trial. Adv Psychiatr Treat 2002; 8:326-333.

6o. Tunis SR, Stryer DB, Clancy CM. Practical clinical trials. Increasing the value of clinical research for decision making in clinical and health policy. JAMA 2003; 290:1624-1632.

61. Roland $M$, Torgerson $D J$. What are pragmatic trials? BM] 1998; 316:285

62. International Conference on Harmonisation of Technical Requirements for Registration of Pharmaceuticals for Human Use. $\mathrm{ICH}$ Harmonised Tripartite Guideline. Choice of Control Group and Related Issues in Clinical Trials E10. July 20, 2000.

63. Carette $S$, Leclaire R, Marcoux S, Morin F, Blaise GA, St-Pierre A, Truchon R, Parent $F$, Levésque J, Bergeron $V$, Montminy $\mathrm{P}$, Blanchette $\mathrm{C}$. Epidural corticosteroid injections for sciatica due to herniated nucleus pulposus. $N$ Engl J Med 1997; 336:1634-1640.

64. Karppinen J, Malmivaara A, Kurunlahti $M$, Kyllönen E, Pienimäki T, Nieminen $P$, Ohinmaa A, Tervonen O, Vanharanta $H$. Periradicular infiltration for sciatica: A randomized controlled trial. Spine ( $\mathrm{Ph}$ ila Pa 1976) 2001; 26:1059-1067.

65. Manchikanti L, Giordano J, Fellows B, Hirsch JA. Placebo and nocebo in interventional pain management: $A$ friend or a foe - or simply foes? Pain Physician 2011; 14:E157-E175.

66. Smuck M, Levin JH. RE: Manchikanti L, Singh V, Falco FJE, Cash KA, Fellows B. Cervical medial branch blocks for chronic cervical facet joint pain: A randomized double-blind, controlled trial with one-year follow-up. Spine (Phila Pa 1976) 2008; 33:1813-1820. Spine (Phila Pa 1976) 2009; 34:1116-1117.

67. Ghahreman A, Ferch R, Bogduk N. The efficacy of transforaminal injection of steroids for the treatment of lumbar radicular pain. Pain Med 2010; 11:11491168.

68. Chou R, Atlas SJ, Loeser JD, Rosenquist RW, Stanos SP. Guideline warfare over interventional therapies for low back pain: Can we raise the level of discourse? ] Pain 2011; 12:833-839.
69. Indahl A, Kaigle AM, Reikeräs $\mathrm{O}$, Holm $\mathrm{SH}$. Interaction between the porcine lumbar intervertebral disc, zygapophysial joints, and paraspinal muscles. Spine (Phila Pa 1976) 1997; 22:2834-2840.

70. Indahl A, Kaigle A, Reikeräs O, Holm S. Electromyographic response of the porcine multifidus musculature after nerve stimulation. Spine (Phila Pa 1976) 1995; 20:2652-2568.

71. Pham Dang C, Lelong A, Guilley J, Nguyen JM, Volteau C, Venet G, Perrier C, Lejus C, Blanloeil Y. Effect on neurostimulation of injectates used for perineural space expansion before placement of a stimulating catheter: Normal saline versus dextrose 5\% in water. Reg Anesth Pain Med 2009; 34:398-403.

72. Tsui BC, Kropelin B, Ganapathy S, Finucane B. Dextrose $5 \%$ in water: Fluid medium maintaining electrical stimulation of peripheral nerve during stimulating catheter placement. Acta Anaesthesiol Scand 2005; 49:1562-1565.

73. Pasqualucci A, Varrassi G, Braschi A, Peduto VA, Brunelli A, Marinangeli F, Gori F, Colò F, Paladini A, Mojoli F. Epidural local anesthetic plus corticosteroid for the treatment of cervical brachial radicular pain: Single injection verus continuous infusion. Clin J Pain 2007; 23:551-557.

74. Mao J, Chen LL. Systemic lidocaine for neuropathic pain relief. Pain 2000; 87:717.

75. Pasqualucci A. Experimental and clinical studies about the preemptive analgesia with local anesthetics. Possible reasons of the failure. Minerva Anestesiol 1998; 64:445-457.

76. Arner S, Lindblom U, Meyerson BA, Molander C. Prolonged relief of neuralgia after regional anesthetic block. A call for further experimental and systematic clinical studies. Pain 1990; 43:287-297.

77. Lavoie PA, Khazen T, Filion PR. Mechanisms of the inhibition of fast axonal transport by local anesthetics. Neuropharmacology 1989; 28:175-181.

78. Bisby MA. Inhibition of axonal transport in nerves chronically treated with local anesthetics. Exp Neurol 1975; 47:481-489.

79. Manchikanti L, Singh V, Falco FJE, Cash KA, Pampati V. Evaluation of the effectiveness of lumbar interlaminar epidural injections in managing chronic pain of lumbar disc herniation or radiculitis: A randomized, double-blind, controlled trial. Pain Physician 2010; 13:343-355. 
8o. Manchikanti L, Cash KA, McManus CD, Pampati V, Benyamin RM. Preliminary results of a randomized, double-blind, controlled trial of fluoroscopic lumbar interlaminar epidural injections in managing chronic lumbar discogenic pain without disc herniation or radiculitis. Pain Physician 2010; 13:E279-E292.

81. Manchikanti L, Cash KA, Pampati V, Wargo BW, Malla Y. Cervical epidural injections in chronic discogenic neck pain without disc herniation or radiculitis: Preliminary results of a randomized, double-blind, controlled trial. Pain Physician 2010; 13:E265-E278.

82. Manchikanti L, Cash KA, Pampati V, Wargo BW, Malla Y. The effectiveness of fluoroscopic cervical interlaminar epidural injections in managing chronic cervical disc herniation and radiculitis: Preliminary results of a randomized, double-blind, controlled trial. Pain Physician 2010; 13:223-236.
83. Manchikanti L, Cash KA, McManus CD, Pampati $\mathrm{V}$, Benyamin RM. A preliminary report of a randomized double-blind, active controlled trial of fluoroscopic thoracic interlaminar epidural injections in managing chronic thoracic pain. Pain Physician 2010; 13:E357-E369.

84. Tachihara H, Sekiguchi M, Kikuchi S, Konno S. Do corticosteroids produce additional benefit in nerve root infiltration for lumbar disc herniation. Spine (Phila Pa 1976) 2008; 33:743-747.

85. Sato C, Sakai A, Ikeda Y, Sakamoto A. The prolonged analgesic effect of epidural ropivacaine in a rat model of neuropathic pain. Anesth Analg 2008; 106:313-320.

86. Pizzo PA, Clark NM. Alleviating suffering 101 - Pain relief in the United States. N Engl J Med 2012; 367:197-198.

87. Byrod G, Otani K, Brisby H, Rydevik B, Olmarker K. Methylprednisolone reduces the early vascular permeability in- crease in spinal nerve roots induced by epidural nucleus pulposus application. J Orthop Res 2000; 18:983-987.

88. Hayashi N, Weinstein JN, Meller ST, Lee HM, Spratt KF, Gebhart GF. The effect of epidural injection of betamethasone or bupivacaine in a rat model of lumbar radiculopathy. Spine (Phila Pa 1976) 1998; 23:877-885.

89. Lee HM, Weinstein JN, Meller ST, Hayashi N, Spratt KF, Gebhart GF. The role of steroids and their effects on phospholipase A2: An animal model of radiculopathy. Spine (Phila Pa 1976) 1998; 23:1191-1196.

9o. Minamide A, Tamaki T, Hashizume H, Yoshida M, Kawakami M, Hayashi N. Effects of steroids and lipopolysaccharide on spontaneous resorption of herniated intervertebral discs: An experimental study in the rabbit. Spine (Phila Pa 1976) 1998; 23:870-876. 